\title{
The Real, the Mythic and the Psychic in Edward Bellamy's Looking Backward 2000-1887 and Tawfiq Al-Hakim's People of the Cave
}

Nagy Abdel-Raouf Abdel- Dayem

\author{
Prof. Youssef Nofal \\ Professor of Arabic Literature \\ Department of Arabic
}

\author{
Dr. Nadia Abd-Elatif \\ English Department \\ Faculty of Women, Ain Shams University
}

\begin{abstract}
This research demonstrates the relationship between the real, the mythic and the psychic elements in Edward Bellamy's celebrated novel Looking Backward 20001887 and Tawfiq Al-Hakim's well-known play The People of the Cave. First, the research introduces various definitions of the term myth and how it constitutes a fertile soil for writers of all genres of literature. By resuscitating old myths, writers do not mean to imitate those myths but they seek interpretations and solutions to their contemporary issues. Moreover, the research examines the concepts of psychoanalysis, archetypes, collective unconscious as manifested in the writings of Thomas Bulfinch, Joseph Campbell, Sigmund Freud and Carl Gustav Jung for their direct relationship to mythology. While mythology is perceived as a means by which one can have a closer look at religion, culture, history and science, dreams embody the source book that provides one with the knowledge needed to understand the human psyche, its conscious and unconscious states. Then, the research traces the presence of the self, the shadow and the persona archetypes in Bellamy and Al-hakim's works mentioned above.
\end{abstract}

Key words: mythology, dreams, psychoanalysis, Looking Backwards, people of the cave, collective unconscious, archetypes, Al-hakim, Bellamy, Dr. Julian West, Mishlinya.

For mythology is the handmaid of literature; and literature is one of the allies of virtue and promoters of happiness. Without a knowledge of 
mythology, much of the elegant literature of our own language cannot be understood and appreciated. (Bulfinch 1967, 11)

This paper demonstrates how mythology, as a fertile and rich source of literature, has deeply influenced the literary heritage along history.Various definitions of the term mythology come first. Next, the paper examines the concepts of psychoanalysis, archetypes, collective unconscious as manifested in the writings of Thomas Bulfinch, Sigmund Freud and Carl Gustav Jung for their direct relationship to mythology. Then the three frames of reference; Bulfinch's theories, Freud's dream theory and Jung's collective unconscious with its archetypes are applied on Edward Bellamy's Looking Backward 20001887(1887) and Tawfiq Al-Hakim's People of the Cave (1933) as outstanding mythically-grounded literary works in which one could easily trace the effective presence of mythology, dreams and archetypes. Thus, the main objective of this research is to examine the convergence of the real, the mythic and the psychic elements in the selected works and how far the Jungian archetypes are introduced as moving ideas not independent characters. In addition, the research tries to answer the questions; what do dreams and myths have in common? How far has the mythic structure helped Bellamy and Al-hakim to represent the social issues of their times? Does the psyche of Bellamy and Al-hakim have any influence upon their delineation of characters, choice of symbols or the development of their stories?

\section{Mythology}

Definitions of mythology are varied and versatile due to the multiple perspectives of the mythic lesson, its goals and the ubiquitous or interdisciplinary uses of the term in various areas of humanities. Mythology is simply defined as sacred stories often endorsed by rulers or priests, and closely linked to religion or spirituality. 'Myth' is derived from the Greek word muthos which means "'a spoken story of heroes, gods, etc. belief without foundation" (Coleman, 727). Christian Gottlob Heyne (1729 -1812), a German philologist, was one of the forerunners who shaped the modern concept of mythology and the first to coin the word 'myth' as a scholarly term. (Morales, 57) As a word, the meaning of myth has changed along the centuries. Muthos was not necessarily false. A myth may be, in some way, false or else it would be history. (Dowden, 3-4) 
Myth is usually regarded as a true account of the remote past. Many societies develop two categories of traditional narrative: true stories or "myths" and false stories or "fables". (Emelda, Online 2011) This linguistic shift from fable to myth marks the outbreak of a new revolution in the field of literature and fantasy that is comparable to the contemporary political revolutions in America and France. (Hendy, 3) Moreover, Roland Barthes identifies mythology, myths in general, as "a kind of language" (Barthes, 1991, 10). He also considers mythology as "a system of communication..., and a mode of signification, a form. Later, we shall have to assign to this form historical limits, conditions of use, and reintroduce society into it: we must nevertheless first describe it as a form" (Barthes, 1991, 107) Such a form can be conveyed through a discourse that disseminates the message of the myth in accordance with its form rather than its object. Relying on the oral nature of mythology, Barthes sees that every object in the world can become a myth if it manages to pass from a closed silent existence into an oral state ready for appropriation by society. Barthes concludes that all the material of a myth; whether pictorial or written requires a signifying consciousness. (Barthes, 1991, 107-8)

Like Barthes, Levi Strauss considers mythology a form of language that predisposes us to "attempt to understand ourselves and our world by superimposing dialectics, dichotomies, or dualistic grids upon data that may in fact be entirely integrated"'(Strauss, viii). Hence, mythology and language are closely related. It is not just a close relationship but a "real solidarity" that connects language and mythology, and understanding the nature of this solidarity would be the key to "the mythical world" (Cassirer, 17). Accordingly, myths break and are fixed again, lost and found, and the one who could find and fix them is the handyman whom Strauss termed as a "bricoleur" (Strauss, viii) in English, "a rag- and - bone man". Furthermore, each mythic narration draws upon those rags and bones whose history is brought back into the new story. (Strauss ix)

In his seminal study, Mythology in the Contemporary Egyptian Theatre, Ahmed Shams Eldeen Al-Haggagy displays mythology and examines its relation to the roots of drama. Al-Haggagy draws a linear relation between mythology and reality when he defines the former as a kind of ritualistic narrative whose origins are deeply rooted in history. (Al-Haggagy 9) This historical background gives distinction to drama over the other genres of literature since it embodies the ground where mythology first appeared. By and 
large, drama came to existence as a natural outcome of the development of mythology. In addition, mythology has a lot to do with the various stages of life from childhood to adult responsibilities. For example, Joseph Campbell considers turning from the unmarried state into the married a mythological rite in which one recognizes his new role by throwing off his old one and getting into another responsible profession. (Campbell 1988, 14)

Spiritually, the rituals of the myth could give man the possibility of accomplishing the unbelievable goals, hence the real and the phantasmagoric converge and their connection has become inevitable. Accordingly, many dramatists derive their stories from mythology because they believe in its power to interpret the present and preserve the future. (Al-Haggagy 9-11t.m.) Mohammed Zaki Al-Ashmawy reiterates this idea when he considers ancient Greek theatre as a neat representation of Greek and Roman history which is rich in philosophy, culture and ideas that not only trace the development of the human mind but also the high standards man has reached through this art. (AlAshmawy 1994, 8 t.m) As such, mythology offers, according to Joseph Campbell, 'life models' which should be appropriate to the time we live, and the well-known changes which have come over our life in the last few decades. (Campbell 1988, 16)

Joseph Campbell sums up what can be inferred through resuscitating mythology. He perceives mythology as an opening through which the inexhaustible and inexorable energies, religions, philosophies, arts, forms of primitive man, scientific discoveries and dreams boil up through cultural manifestations. (Campbell 2004, 1) Moreover, mythology is used by people of the modern world not just as a kind of analysis handling ancient myth-making but also as a means by which we understand ourselves, our liberties and our lies. (Morales, 4-16) For these reasons, mythology mattered for the Greeks and the Romans, and it also matters for us to understand who we are, where we came from, and what we want to be. In short, it is a magic tool by which authors try to address, interpret reality and find convenient solutions to the issues they face at present.

Can mythology be handled independently and detached from other genres of literature? Solayman Madher grapples with this inquiry in his study Myths from the West (2000). For Madher, one can hardly do research on mythology without shedding light upon folktales and/ or old legends because the three forms 
constitute the traditional cultural heritage of any nation. As for folklore or folktales, they introduce the human heritage in its embryonic state including ancient doctrines, traditions, tales, arts etc. Undoubtedly, those stories are still primitive but they are of mythic origins and have their pure poetic and artistic values. In comparison with myths, folktales have their deeper roots in history since they are well-known for their oral nature unlike myths which were mostly written down. Besides, mythology is seen as a sort of space where religion interacts with history, science with fancy, and dreams with reality. (Alhamdawi, online, 2018)

By tracing the origins of mythology, Bulfinch concludes that philosophers have developed various theories: the scriptural, the philological, the physical or elemental, the historical and the allegorical. In this context, the analysis includes the historical and the allegorical theories in particular for their importance. As for the historical theory, philosophers think of all characters in mythology as real human beings but all the legends and traditions related to them come out as an act of embellishment that took place lately across time. For instance, Cadmus who is said to sow the earth with dragon's teeth was in fact a Phoenician who taught the people of Greece the letters of the alphabet. From a different perspective, the Allegorical theory considers all mythology to be allegorical and symbolical because they contain moral, philosophical or religious facts shaped in an allegorical form which can be understood across the process of time. The power of Saturn who devours his children is very similar to that of Cronos (time for the Greeks) since it destroys whatever it has brought into existence. (Bulfinch, 1967, 375-7)

\section{The Historical Myth in Edward Bellamy's Looking Backward 2000-1887 and Tawfiq Al-hakim's People of the Cave}

With regard to Edward Bellamy's Looking Backward 2000-1887(henceforth will be referred to as ' $L B$ ') and Tawfiq Al-hakim's People of the Cave (referred to as 'POTC'), one would recognize them as mythically grounded on the reminiscences of the ancient myth The Seven Sleepers of Ephesus. Historically, this myth has its origins in Christianity as well as in Islam with slight variation concerning the length of concealment, the number of the youth and the circumstances that surrounded them in the cave. At that time, the Christians had suffered from unprecedented empire-wide persecution and mob violence by the emperor Decius (201 AD - 251 AD) and the followers of the Roman 
Empire. The chain of violence against the Christians was heightened by issuing an edict to execute the Christians who refused to convert to the polytheist religion of his empire. In consequence of such appalling and sovereign orders, a great deal of the Christians concealed their belief and worked secretly till Christianity has become deeply- rooted across the empire. Decius himself admitted this fact at the very moment of his abdication in 305 A.D. (Etman, 231-3t.m.)

Ostensibly, the sleepers were revived in between 425 and 437 A.D. in the reign of the Emperor Theodosius II (401 AD - 450 AD). To their amazement, the sleepers found a new world where religious freedom prevails and Christianity has become the official religion of the empire in place of paganism. Being unconscious of their trance, the sleepers can hardly perceive the magnitude of the metamorphosis which has come over the whole society. Once their secret was revealed, they departed and rested in peace. According to Etman, the historical truth of the story is undisputed as it was not mentioned in the Old Testament but the Holy Qur'an gives an account of the typical story in Chapter 18 (Surat Al-Kahf) and a great deal of the hermeneutics provide various interpretations to assure the reality of such narrative. (Etman, 236-41t.m.)

The contemporaries of those Christian martyrs awaited their eventual return and as a result, a number of myths have anticipated their intrinsic return. Alhakim's story was based upon the account given by Gallias, the tutor of the king who introduced the Christian youth into the play; Mishlinya, Marnush and the shepherd Yamlikha. (Etman, 242- 3t.m.) Thus, Al-hakim has worked on this historical myth. Furthermore, POTC is considered a turning point in the literary career of Al-hakim that is why Ahmed Haikel describes it together with Shaherzad (1934) and Pygmalion (1942) as landmarks in the history of Arabic literature. They represent the first attempt on Al-hakim's theatre of the mind for the social, political and psychological aspects highlighted by the author. (Haikel, 367-8 t.m.) These works appeared shortly after Al-hakim's return from France where he had studied dramaturgy for years. There, he had the chance to read about Greek and Roman mythology whose influence can easily be touched in the works that appeared after 1927. Roger Allen has referred to Al-hakim's desire to "replicate the European tradition was thus timely in the extreme, and it is for that reason that the publication and performance of his play, Ahl al-Kahf (The People of the Cave, 1933) is such a significant event in Egyptian drama"( Allen 201). 
As for Edward Bellamy, the ordinary reader would easily identify the original myth The Seven Sleepers of Ephesus, and surely draws a comparison between the original myth and LB. Bellamy's purpose is somehow different from that of Al-hakim's since his main concern was to display the social, economic and political issues of his time. By nature, Bellamy was a nationalist who believed in the revolution to achieve his dream of radical change in all fields of life. Besides being a philosopher, he had the mentality of a visionary which was evident in the way he structured his novel $L B$ one hundred and thirteen years ahead. He had the ability to foresee the future of his nation amid such a turbulent atmosphere of social inequality and the rising economic and political crises. When he was asked why he wrote $L B$, Bellamy replied:

It is only just to myself to say, however, that this should not be taken to indicate any difference to the miserable condition of the mass of humanity, seeing that it resulted rather from a perception all too clear of the depth and breadth of the social problem and a consequent skepticism as to the effectiveness of the proposed solutions which had come to my notice. (Bellamy 1937, 199)

On parallel lines, Arthur E. Morgan sheds light upon the organized concept of the relations between people in a good society as presented by Bellamy in $L B$ as well as in other works. This concept concretizes Bellamy's philosophy as both a working plan and program for his life. Morgan thinks of Bellamy not only as a social reformer but also as "a writer of psychological studies in fiction form" (Morgan, 1). In addition, Morgan thinks of Bellamy as a philosopher who has rebelled against the tyranny of life and manages to become free to face the truth. He is determined not to submit to servitude. He enjoys a fresh look at life and his position makes him able to look into the abyss. (Morgan, 1-3)

\section{Allegory and symbols in both Works}

Allegorically, Bellamy and Al-hakim have intentionally designed $L B$ and POTC to expound the eternal conflict between man and time. Both writers are keen to avoid the inevitable effects of time and reduce its influence to minor appearances. The main character in $L B$ manages to survive the great fire which has wiped out his mansion and as a result, he becomes a memory in time while being hypnotized in his protected cellar by his servant Sawyer. In POTC, the major characters and their dog have also survived decay not by being 
hypnotized like West but by divine providence as a reward for their religious belief and as a clear manifestation of God's omnipotence as well; "the mystery of God's actions; faith and piety" (Fudge, 73). Originally, both works handle the struggle against time to show that "whereas intellect and common sense inevitably fail in trying to resist the movement of time, only love and the heart can triumph over it" (Badawi 1988, 956).

Symbolically, $L B$ and $P O T C$ represent a private myth and a public dream respectively, since $L B$ embodies Bellamy's own aspirations for the future while POTC illuminates the way for the nation to go ahead regardless of the shackles preventing its development. In $L B$, Bellamy manages to introduce two totally different worlds separated chronically but connected spatially. The first world is a neat representation of the nineteenth century with its social, economic, political and ideological ailments while the second one, the twentieth century, is enhanced by miraculous changes that doomed all fields of life. Technology has become of conspicuous importance and equal opportunities are guaranteed for all members of the society. This sharp contrast between the two worlds is clearly manifested through many images.

For example, the industrial system of the nineteenth century "with all its shocking social consequences" in which Julian West sees himself as "Living in luxury, and occupied only with the pursuit of the pleasures and refinements of life, I derived the means of my support from the labor of others, rendering no sort of service in return" (Bellamy 2009, 3-5) had caused strikes, tensions, struggles, arguments and even rebellions came to the ground as a result of the injustices done to the downtrodden masses. Such an image has completely changed in the twentieth century as revealed by Doctor Leete when he told West "'Only a century has passed,' he answered, 'but many a millennium in the world's history has seen changes less extraordinary' ... 'Seeing that this house is built on the site of your own, I hope you will find it easy to make yourself at home in it" (Bellamy 2009, 23). The symbolism of these phrases is quite clear as the new house and the old one symbolize the two disciplines of the nineteenth and the twentieth centuries and the repercussion of this massive change far exceeds a century long. West himself was ready to accommodate himself in the new discipline

After my refreshment Dr. Leete offered me a bath and a change of clothing, of which I gladly availed myself. It did not appear that any 
very startling revolution in men's attire had been among the great changes my host had spoken of, for, barring a few details, my new habiliments did not puzzle me at all.

Physically, I was now myself again. But mentally, how was it with me, the reader will doubtless wonder. What were my intellectual sensations, he may wish to know, on finding myself so suddenly dropped as it were into a new world.... The impressions of amazement and curiosity which my new surroundings produced occupied my mind, after the first shock, to the exclusion of all other thoughts. (Bellamy 2009, 23-4)

Likewise, Mishlinya, Marnush and Yamlikha the sleepers in Al-hakim's cave have experienced a long-term hypnotism. All their accumulated memory of the past is kept in their minds since they represent an era in history and a preserved idea in Al-hakim's mind as well. Tacitly, they are animated in utter darkness where their backs and ribs hurt because of the long sleep as they understand. Unconsciously, they are unaware of sleeping for centuries in the cave:

Mishlinya: ... how long did we stay here?

Marnush: A day or may be less than that.

Mislinya: How did you know?

Marnush: I wonder if we could sleep more than that.

Mishlinya: You are true, (silence), (suddenly, he says in a far-sighted way), I want to get out of this place.

Marnush: Damn, where to?

Mishlinya: Do you want me to spend another night here! (Al-hakim 2008, 7-8 t.m.)

In terms of Bulfinch's philosophical theories, $L B$ and POTC could be classified as both historical and allegorical. First, the myth is deeply rooted in the history of theology both in Christianity and Islam. Next, The Seven Sleepers of Ephesus provides information about the nature of relationships between the social strata within their culture. It also introduces a way in which a culture preserves its history, social crisis, struggles as well as a guide on how people should act towards each other in the material world. In addition, the myth tells about the relations between human beings, their sovereign and their heroic deeds. (Dant, 21)

In a similar vein, $L B$ and $P O T C$ managed to introduce a credible image of life in America and Egypt during the late nineteenth and early twentieth century 
respectively. Like The Seven Sleepers of Ephesus, LB and POTC are handled as originating stories taking place in some particular time in history because they are "full of allusions to matters that would be best known to people of that time and place" (Ellwood, 6). Moreover, both works inherited a kind of spirituality that made them close to nature and the soil "that was symbol based, that was expressed in accounts of heroes and other archetypes rather than individual figures" (Ellwood, 6). Thus, reviving the old myth proves to be of great relevance to a modern need. Nora Lee Willi stressed this need in $L B$ when she highlighted Bellamy's objective "Bellamy calls on his audience to look upon their current position through the long lens of history--if they could do that, he thought, then the way before them would be clear" (Willi, 116).

Accordingly, $L B$ and POTC prove to be typical representations of dreamy visions since they reflect the double vision of inward and outward, past and future, reality and dreams, death and rebirth. Despite sharing the origins of the same historical myth, $L B$ and POTC are structured differently. $L B$ is represented in a narrative form and used the first person narrator technique in order to give free reins to Bellamy's internal conflict whereas POTC is shaped in a dramatic form where dialogue is employed to dramatize both the internal conflict within Al-hakim's psyche and the external one with time. In response to an inquiry about his intention to stage POTC, Al-hakim admitted writing POTC to be read not to be acted on the stage. He added that "if I had the ability to represent the idea in a poem, a painting or even in a piece of music, I would definitely do" (Shaheen, 133-4 t.m.)

Thus, Al-hakim intended to design a narrative form at the very beginning but the influence of the mental theatre made him turn to drama where characters can easily be introduced as moving ideas attired in symbolic dresses. What matters here is the idea not the incident and this would justify Al-hakim's intention to keep the play away from the stage. (Haikel, 369) Deliberately, he did not include POTC, Scheherazade or Pygmalion in either of the volumes he dedicated to his plays. He had fears of misrepresenting them on the stage. He was quite sure that his audience would hardly understand the nature of the conflict between man and time on the one hand or man and the locale on the other. (Al-hakim 1942, 12-14) Likewise, Bellamy considered LB a small book that could not include all what he wished to introduce and what was left behind was far more important so he felt obliged to write another book utilizing the framework of $L B$ as a starting point. (Bellamy, 2007, 7) This simply means 
neither Bellamy nor Al-hakim would give up either dreaming or reviving old mythology.

Why do mythology and dreams matter crucially for Bellamy and Al-hakim? Generally, mythology is shaped in symbolic form and deals with the process of maturation starting from dependency through adulthood, maturity and to the exit, relating all along to a certain society, then relating such society to the world of nature and finally to the cosmos. (Campbell 1988, 41) Unconsciously, these symbolic images move from generation to generation, they handle the inner mysteries of life, and function as a source of light-giving in order to teach us a lesson; daylight follows darkness. As a matter of fact, the great similarities myths, from various areas of the universe, have in common go back to their origins as they represent magnified images of the human psyche. The incidents and the conflicts in mythology embody the internal conflict within the self. Consequently, Campbell delineates the psyche as an all-inclusive entity.

\section{Psychoanalysis and Dreams}

What is happening in the psyche is normally reflected through dreams by relating those psychic events to either past or contemporary life experiences. Intrinsically, dreams constitute a source of spiritual information about ourselves. If a dream represents a personal experience, it is a private myth then. (Campbell 1988, 48) Furthermore, we could refer to Carl Jung's perception of dreams as "the facts from which we must proceed" (Jung, 1989, 171). Therefore, dreams could be employed to study both mythology and the human psyche.

Therefore, psychoanalysis was founded by the Austrian neurologist Sigmund Freud (1856-1939) as a clinical method for treating people with psychological or mental disorders through dialogue with the psychoanalyst. Later on, this theory had its irrevocable impact upon cultural and literary thought in the twentieth century. Helen Morales equates psychoanalysis with Greek mythology to the extent that both of them constitute the two sides of a medallion and neither of them could be studied without reference to the other. Their relationship is dynamic and Freud takes a central stage for being passionate about Greek mythology for using myths as points of reference or comparison in his analysis of the psyche. (Morales, 69-73) 
In addition, myths could be used as case studies from which conclusions could be drawn about universal experiences. Therefore, Joseph Campbell stresses the need for utilizing mythology to interpret dreams: "On some levels a private dream runs into truly mythic themes and can't be interpreted except by an analogy with a myth" (Campbell 1988, 49). Dreams, for Campbell, arise from mythology or include mythic themes and this could be seen as emblematic of "the Christ within" (Campbell 1988, 49). Dreams give voice to the mysteries of our inner life through a set of images derived from mythology which handle prototypical problems in various cultures. They represent the invisible "rhizome" which remains so that Carl Jung considers it the most important in life rather than the blossom which is ephemeral. (Jung, 1989, 4)

Similarly, Freud saw the psyche as imagination; unfailing source of fiction and interpretation. Hence, psychoanalysis was in some respect literary. In his epoch-making book The Interpretation of Dreams (1911), Freud addresses the basic concepts of psychoanalysis and how dreams, memories of childhood, relationships with the parents and the social milieu are repressed in the unconscious and thus made inaccessible to the conscious mind of the patient. Freud thinks that a great deal of the human psyche lies hidden from the conscious mind and it is only reachable through manifestations of the unconscious.

\section{What do Myths and Dreams have in Common?}

What myths and dreams have in common is that dreams arise from individual emotions and such emotions are common to all mankind. They can be expressed in what Freud identifies as "typical dreams". Dreams can be traced back to waking wishes (daydreaming) and those wishes constitute the nucleus of certain myths. Plausibly, typical dreams would serve as a starting point for analyzing and investigating the wish theory of dreams because, according to Freud, there is a repressed wish in the unconscious at the very beginning of every dream. During his life, the individual experiences events or episodes which may never be recalled without causing great pain. To avoid such pain, the individual seeks forcing such reminiscences out of his consciousness but that pain cannot be fully diminished with the passage of time; instead the individual represses them into the unconscious. Apparently, they are withdrawn from the spontaneous recalling but whenever the consciousness is weakened and phantasy replaces logical thought as in daydreaming, the repressed psychic 
material is freed. Thus, the repressed wishes come back to expression. (Abraham, 4-5)

Another point of similarity between dreams and myths is demonstrated by Freud when he refers to infantile phantasy activity with its objects which continue to appear frequently in later stages of the individual life as analogous to myths which arise from a specific era in the history of a certain people. This early period is designated as the childhood of that race. While dreams reproduce fragments of infantile reminiscences, memories of childhood or repressed wishes, myths are originated in prehistoric times and seek to revive indefinite traditions of that far past. Consequently, a myth is "a fragment of the repressed life of the infantile psyche of the race. It contains (in disguised form) the wishes of the childhood of the race" (Abraham, 36).

Synthesized with historical analysis, psychoanalysis could interpret social, cultural or even religious rites. For example, in Egypt people celebrate Sham ElNaseem day which marks the beginning of spring. It falls on the day after the Eastern Christian Easter. Without prior knowledge of that day, one can hardly understand what that day connotes, means or signifies. The memory of that day is derived from the ancient Egyptian mythology so comparatively the celebrations are linked to those of the ancient Egyptians. Another example is mentioned by Carl Jung when referred to what the baptismal rite means. When a child is baptized he is admitted into the Christian community but this seems unsatisfying for us as ordinary people since sprinkling a child with water does not give a satisfactory answer. Searching into the history of the rite, one would undoubtedly find that baptism is a rite of initiation and consecration performed with water; the source of life in all religions. (Jung, 2012, 64-5) This is how reminiscences and memories are recollected from history or mythology to interpret present realities, traditions or rites. In a similar way, Bellamy's protagonist Julian West refers to a national day that would surely be preserved in history to commemorate the heroic deeds of a national event carried out by heroic characters:

The thirtieth day of May, 1887, fell on Monday. It was one of the annual holidays of the nation in the latter third of the nineteenth century, being set apart under the name of Decoration Day, for doing honor to the memory of the soldiers of the North who took part in the war for the 
preservation of the union of the States...the ceremony being a very solemn and touching one. (Bellamy 2009, 12)

This description functions both as a guide to the history of the nineteenth century and an incentive for Bellamy's audience to become nationalists.

To understand a dream, the psychoanalyst searches into mythology, religion, folklore and history for meaning for every part of the dream in his endeavor to reconstruct and discover a psychological background for the dream. Consequently, Jung shares Freud's view that a dream is only a façade of a vast edifice. This view is not grounded upon any religion or any prior idea but upon empiricism and experience. Any psychic fact, for Freud and Jung, has a wide range of causes and every existent mental element results from an interior psychic state that can be analyzed theoretically. Succinctly, dreams are idiosyncratic in a sense as they vary according to the type of the dreamer. A dream of a child is different from that of a grown up while an illiterate person dreams differently from an educated one but all dreams are "the result of our psychic past. Our present mental state depends upon our history. In each person's past there are elements of different value which determine the psychic "constellation"' (Jung, 2012, 25-26). Thus, a dream can be seen as an illuminating example of the psychic content and a tacit manifestation of the unconscious. Therefore, Jung calls a dream symbolic, because "it is a psychological product whose origin, meaning, and purpose are obscure, and.is therefore one of the purest products of unconscious constellation" (Jung, 2012, 66)

\section{Jung and the Collective Unconscious with its Archetypes}

If the Freudian theory enables us to see into the individual Psyche and discover what is not uttered, Carl Jung has projected profoundly into the unconscious mind to provide us with engaging data about another major constituent of the unconscious mind rather than that of Freud namely the collective unconscious. Jung has distinguished the collective unconscious from the personal unconscious in that the former is inherited while the latter is acquired through personal experience i.e. the first could be related to history and heredity while the latter is empirical. According to Jung, the concept has been received with so much misunderstanding for the negative differentiation between it and the unconscious. (Jung 1980, TCW v9, 42) Although the personal unconscious lore has passed through the conscious channels and has 
been forgotten or repressed due to a certain reason or another, the contents of the collective (impersonal) unconscious have never gone through those channels of the conscious mind. It is noteworthy to tell about the reason beyond employing the collective unconscious in this paper. The collective unconscious allows comparing works mythically grounded on the same myth such $L B$ and POTC.

The importance of the collective unconscious is imputed to the nature of its content which Jung conceptualizes as the archetypes. An archetype is identified by Oxford Concise Companion to English Literature as "a primary symbol, action, setting or character- type that is found repeatedly in myth, folklore, and literature" (24). Similarly, Chris Baldick defines an archetype as a "theme ...that recurs in different times and places in myth, literature, folklore, dreams, and rituals ...it embodies some essential element of 'universal' human experience" (Baldick, 23). The concept of archetypes is a concomitant correlate of the collective unconscious because both concepts actually bespeak the existence of certain forms in the psyche. Jung has drawn attention to the variety of names under which the archetypes may be assumed for example; they are called "motifs" in mythology, "representations collectives" in primitive psychology, and "categories of the imagination" or "Primordial thoughts" in the field of comparative religions. (Jung 1980, TCW v9, 42-3)

Is the manifestation of the contents of the collective unconscious (archetypes) typical in all dreams/ visions? According to Carl Jung, the immediate manifestation of archetypes is not typical but individual and less understandable. Essentially, the archetypes are unconscious contents which can be altered by "becoming conscious and by being perceived" (Jung 1980, TCW $\mathrm{v} 9,5)$. Normally, the archetypes take a great deal of their attire from the individual consciousness where it evolves. Joseph Campbell adds another dimension to the concept of "elementary ideas" (archetypes) for their appearance all over the world and in different times of human history. As a matter of fact, the archetypes appear in different costumes due to environmental and/or historical conditions. They come from below and they suggest further work ahead. This idea is palpably present in $L B$ and POTC since both have relied upon the same myth but their characters appear in different attires. In $L B$, Julian West adapted to the twentieth century to prove Bellamy's aptitude and enthusiasm for change whereas in POTC, the Christian youth can hardly take 
off their old attire or even cope with their folks because of the tremendous changes that took place while they were away.

Archetypes are different from Freud's complexes as they are biologically grounded whereas Freud's are biographical and repressed traumatic experiences from one's lifetime. While the archetypes of the unconscious are manifestations of the organs of the body and their powers, the Freudian unconscious is personal and biographical which is secondary to biological. (Campbell 1988, 60-61) Another noteworthy difference between Freud and Jung's perception of mythology can be regarded in the way each of them interpreted myths. For Freud, myths can be interpreted in the light of psychoanalysis but as for Jung, mythology expresses an archaic unconscious which is characteristic of its people thus giving rise to psychological types. (Roudinesco, 147)

Basically, archetypes embody the blueprints of our personalities since each individual is both shaped and influenced by those ancient psychic templates which occasionally erupt from the unconscious and manifest themselves as symbols, ideas or images. Intuitively, we recognize them through their effects in our lives because their forms and patterns show up as our behavior, mental and emotional habits. Tacitly, they play their role "in the form of image schemas which are experienced in non-verbal, implicit and embodied ways, rather than as pre-existing fully fledged symbolic meanings waiting to be activated" (Knox, 10). The process of activation is undertaken by analyzing the constellation of images and pinpointing their ability to symbolize, to connect past and present experiences in order to expose a meaningful story in which one could reasonably be related to others.

Although there is no limit to the number of archetypes that may exist, Carl Jung has identified four major archetypes namely the self, the shadow, the persona/mask and the anima/ animus. In this paper, light is shed on the self, the shadow and the persona /mask for the limited space. The self-archetype represents the dual aspects of the individual; conscious and unconscious. The self also appears as a mandala or a circle in which the various aspects of personality are integrated. If the conscious and unconscious aspects of the self unite, what Jung conceptualizes as "individuation" appear to play a major role in psychology since the conscious and unconscious come to know, respect and accommodate each other. By individuation, the individual beings are formed and differentiated. They become also distinct from the general collective 
psychology. Thus, individuation has for its general goal, the development of the individual personality and the realization of its uniqueness.

The process of individuation is complete when "the conscious and the unconscious have learned to live in peace and to complement one another" (Jung 1988, 14). For Jung, man becomes calm, whole, happy, fertile and integrated with the fulfillment of the process of individuation. In this respect, individuation does not seek isolation for the individual but helps giving more freedom for the latent content of the psyche as Marie- Louise Von Franz says: "individuation does not mean some egotistical isolation, but on the contrary, it creates the precondition for genuine relatedness and a sustainable social attitude" (Franz 2014, 151). The most striking example of the concept of individuation is embodied in Apollo as he himself is a glorious incarnation of a divine image. Nietzsche and Jung see Apollo as both capable of "ruling over the beautiful illusion of the inner world of fantasy and the god of all shape- shifting powers". Apollo simply signifies "measure, number, limitation, and subjugation of everything wild and untamed" (Jung 2017, 127). To sum up, individuation does not handle the individual as a separate being because his existence presupposes a collective relationship and as a result, individuation should lead to more intense and broader collective relations for a cohesive self.

\section{Archetypes in both $L B$ and POTC}

Archetypally, Bellamy and Al-hakim have largely employed primordial thoughts from the original myth and attired them in various colors to serve their purposes. In $L B$ and POTC, light is focused on the major character that accompanies the reader along the narrative or drama and disappears with the curtains drawn. Dr. Julian West and Mishlinya do this role in $L B$ and POTC respectively. Consciously, both characters live a normal life, have their issues and their temporal sleep emphasizes their separation from the present. Hence, their dream incarnates the gap that keeps them off the conscious world. Their animation has not resulted in any negative consequences till later on when they begin to perceive the real distance separating them from their folks and their conscious time however, quasi-similar people, conditions and architecture confront them after reanimation. West in his conscious state is insomniac but;

His insomnia is manifestly a physiological symptom of the feverish social unrest disturbing the confidence of the terrified middle classes at this time. America is prostrated by a 'great business crisis'. It is disabled 
too by 'disturbances of industry': 'the working classes had quite suddenly and very generally become infected with a profound discontent with their condition, and an idea that it could be greatly bettered if they only knew how to go about it. (Beaumont2005, 71)

Thus, West's hypnotism could be interpreted as a counter response to his social pressures. Like West, Mishlinya responded to the pressures of his time as the real culprit of such dilemma because "he is the typical lover, sensitive and impulsive: on account of his love for the princess, he has exposed his own life (as well as his friend's) to danger and is prepared to do so again" (Badawi 1987, 29). Both protagonists have surrendered directly before the crisis for fear of the apocalypse (execution) which has been a threat to their existence.

Generally, fear was about to take place but the unconscious ushers in an exemplary way out. "An 'impending social catastrophe' is expected. West's desperate retreat into his unconscious is an escape from the "nervous tension of the public mind'. It is also a flight from history itself: West sleeps until the year 2000" (Beaumont2005, 71-2). West's fear made him sleep not just till the next century but continued to the century after. On parallel lines, Mishlinya's revival after centuries of concealment just results in physical weariness; was it the weariness of sleep or of a conscious burden? Was it history that irritates or a sort of physical fatigue of maintaining a physical state for a long time? Was the conscious mind really idle for so long? The same questions are also due to West. Regarding West, the conscious aspect triumphs over the unconscious as he adapts to the future faster than expected and continues his love affair with Edith Leete the quasi-similar to Edith Bartlett his old betrothed.

Hence, the conflict between both aspects permeates their relationship; West and Mishlinya. West's biased inclination towards dream and the future allows for possible success of his attempt to "reconcile his American cultural inheritance with modern American life-puritan guilt with democratic free will, individualist initiative with Darwinian evolution, agrarian values with industrialism" (Guarneri 151). While Mishlinya's gloomy inclination towards the darkness of his psyche caused him to end in despair and surrender to defeat in his confrontation with time. He glimpses the sacred cross he gave to his beloved Edith one day before his hypnotism however; Priska is indifferent as she is not the one who received the cross. The Pseudo lady has gone but her 
memory is alive whereas present Priska is alive physically but spiritually she has no existence in his world. (Belhaj, 612 t.m.).

As for the shadow archetype, it represents a major portion of the unconscious mind which is composed of repressed ideas and emotions such as fear, anger, weaknesses, desires, instincts, grief, shame as well as other aspects of our personality, we think or feel, are not good. It also includes the sex and life instincts. The shadow is considered the darker side of our psyche where our wild, turbulent experiences and chaotic nature are repressed. Marie D. Jones perceives the shadow as "our opposing, amoral, instinctual, and primitive side associated with the past" (Jones, 10). For Jones the shadow represents the animal side to us which is survival- based and can be classified as both creative and destructive powers. It has its negative connotation that makes us not ready to acknowledge its existence. In addition, the shadow embodies the inferior and undeveloped aspects of our personality.

As for its animal tendencies, Jung believes that the shadow inherited them from pre-human ancestors. It can be manifest either individually or collectively in the world as dark or even demonic activity. (Jones, 37) It is not necessarily to be human; the shadow may be a natural phenomenon, a whim, a kind of phobia or any other element that causes anger or fury. "The shadow is a moral problem that challenges the whole ego-personality, for no one can become conscious of the shadow without considerable moral effort. To become conscious of it involves recognizing the dark aspects of the personality as present and real" (Jung 1961CW, 4012). The shadow may also be the "nemesis" of Northrop Frye which appears in an act of vengeance, or to right the balance if there is any violation of law or order. (Frye 2000, 210)

The shadow in $L B$ and POTC represents the darker side of Bellamy and Alhakim's psyche so it incurs fear, weaknesses, anger and grief that arise from the chaotic nature of turbulent protagonists; West and Mishlinya. It has also emphasized its hostile nature to both characters with the development of their stories. Time incarnates the shadow here as it represents the hard rock upon which all dreams, hopes, wishes, aspirations or promises are terminated, annihilated, or lest prevented. West's relationship with time is reluctant, turbulent, and not consistent because of the abhorrent experiences it preserves. West's perception of the nineteenth century is scary and shocking since his memory of this century fearfully reveals oppression, lack of equality or 
democracy. Although it holds suffering on the long run, he accepted the job offered as an historian of the nineteenth century.

Unlike the nineteenth century, West's relationship with the twentieth century is harmonious and intimate to the extent that he does not try to recall his reality and continues to dream. In addition, he is healed from his chronic ailments; inequality no longer appears- services, work, health and education are equally distributed and justice prevails. Technology has achieved giant leaps and luxury is no longer confined to any specific class, race or group of people. Empirically, the accumulated reminiscences of the past, the broken mirrors and pots of antiquity profoundly influence the collective unconscious and as a result, they color the reaction towards the tyrant time. Mishlinya has gone through a similar experience with time but the other way round.

At the very beginning, Mishlinya has denounced the effects of time although he keeps on recalling the sweet and bitter memories he had together with Marnush and Priska before their concealment. Here, time seems to be neutral but later on when Mishlinya tries to violate the natural order and resume his love affair like West, time metamorphosed into its evil nature and starts to throw stones into the quiet sea. Mishlinya becomes more furious when the light starts to illuminate the darkness of the cave. That light is the light of truth and the cave is the human psyche which could not resist the impact of that light. The backlashes of time forced not only Mishlinya but also Marnush, Yamlikha and even their dog to withdraw. The power of time outweighs their poor capability; therefore they departed one after the other: "Has this duel with time been destined to end in its victory? (after a while) yeah.... I am fatigued... fatigued of speech and thinking....of life.....but also...of dream.....this is not life......but a turbulent dream....to the truth then.." (Al-hakim 2008, 104-105 t.m.)

Moreover, West and Mishlinya have experienced shifts of views whether positively or negatively. For example, Mishlinya in his trials to defeat time was tempted by a dream where Priska comes into the cave seeking confession of love but the whole situation turns out to be ironical since Priska admitted coming to the cave only when she was certain about Mishlinya's death. (Alhakim 2008, 108) Likewise, West's fear of return to the past made him develop a kind of phobia concerning the city: "In particular, the apocalyptic quality of West's nightmare of returning to the nineteenth century stems from the force of 
Bellamy's parabolic description of the city as the epitome of a specifically modern form of alienation" (Beaumont 2005, 24).

In short, the shadow archetype is delineated as a high fence enclosing the stage where $L B$ and POTC take place, and whenever any of the characters develops a desire to jump over this high fence, the fence moves inward to narrow the space and cause anxiety to those characters. In order to allow their characters relish the triumph over time, Bellamy and Al-hakim use a similar compensatory mechanism to achieve this goal. Bellamy was intrigued by the idea that "the same personality is made up of separate individualities at various periods" (Shurter 230). Due to this mechanism, Edith Leete is described as a clone of Edith Bartlett, and modern Priska is as well a clone of an old one. Nevertheless, the shadow archetype is time which annihilates all of them in its usual devastating manner. The estrangement and alienation of Mishlinya in the modern age equates the irony of employing West as an historian of the nineteenth century. The meticulous efforts of Bellamy and Al-hakim to marginalize, weaken or retard the effects of time have not proved to be successful for being unnatural and would cause strike to the environmental balance.

The last archetype to be highlighted is the persona/mask. It appears in dreams and takes a number of different forms but if one manages to become identifiable with this archetype, he may not be able to identify his true self. Psychologically, the persona functions dually; to make specific impressions on other people and to conceal the individual's inner self from those who severely criticize him. (Jung 1988, 287) Practically, we bring up our children through a long course on how to behave in certain ways to conform to our society's expectations and norms. Instead of interpreting daily life in mythic story terms, showing out characters and noble ways of accomplishing one's goal by utilizing mythic themes to help rebalance, educate and energize the psyches of the young (Campbell, 2004, $\mathrm{x}$ - The Hero) we exactly 'stage manage' our performance and others will react to this "We may act the part of perfect mother, daughter, doctor, receptionist, spiritual seeker, wise being, until we forget that this is only a role we have decided to play" (Crowley, 51-2). Hence, we develop certain kinds of masks to contain all of our primitive desires, emotions and impulses which may seem socially inacceptable. Psychologically, the more masks the individual dresses in, the more archetypal images we have. Whether consciously or unconsciously one is masked to show what he is not true. The 
mask hides not only the true identity but also represses genuine traits or emotions. "In dreams, the things we dared not speak of or think about had their freedom of expression, and that expression occurred as symbols to be understood by the subconscious mind"(Jones 32). Accordingly, the persona/ mask is not the real self but another one temporally summoned to do a job which contradicts or does not match a certain conviction of the Id. The persona/mask can be utilized to perform a family role, or largely to show our place in the community. It functions as a high wall which keeps one's privacy hidden, and it also allows one to be harmoniously included as a part of the greater social order. In minor cases, the mask manifests a charitable identity and hides a devilish one that seeks fame or sound reputation largely among masses seeking political, religious or social triumphs. The crafty one who practically acquires such malleability to be colorfully-attired enjoys a kind of complex, multi-layered profound personality that is capable of performing multiplicity of roles.

In $L B$ and $P O T C$, there are various instances of characters who work dually along the stories. For example, Marnush and Mishlinya have long worked for the pagan emperor undercover while in reality they were against his policy of execution and his polytheist religion. Even Priska, the old betrothed has functioned typically like both men. The three characters have masked their Christian belief for fear of the dire consequences of opposing the emperor. The same feature could be attributed to Julian West who has never held a taste for the nineteenth century from which he has arisen and after animation he received a job as a $19^{\text {th }}$ century historian. Another example of the persona/mask archetype is consciously used through the narrative by West himself when refers to the working masses attired in the mask of satisfaction and, at the same time, the bourgeoisie attired in dissatisfaction:

For thirty years I had lived among them, and yet I seemed to have never noted before how drawn and anxious were their faces, of the rich as of the poor, the refined, acute faces of the educated as well as the dull masks of the ignorant. And well it might be so, for I saw now, as never before I had seen so plainly, that each as he walked constantly turned to catch the whispers of a spectre at his ear, the spectre of Uncertainty. "Do your work never so well," the spectre was whispering,-_"rise early and toil till late, rob cunningly or serve faithfully, you shall never know security. Rich you may be now and still come to poverty at last. Leave 
never so much wealth to your children, you cannot buy the assurance that your son may not be the servant of your servant, or that your daughter will not have to sell herself for bread." (Bellamy 2009, 187)

What can be inferred through this mask is clear, people of the nineteenth century; the poor and the rich alike lack the spirit to effect change so they conform, against their repressed wishes, to the cruel discipline of the society. West has also remembered the atrocities of the slave trade when he marches close by the harbor. He never forgets the sounds of those slaves groaning: "Like the starving bands of mongrel curs that infest the streets of Moslem towns, swarms of half-clad brutalized children filled the air with shrieks and curses as they fought and tumbled among the garbage that littered the court-yards" (Bellamy2009, 189). Such process is repeated whenever a slave ship reaches the harbor. This sight has disappeared from the twentieth century but it is deeplyrooted in the mind of the Author and Julian West as well. Time has subdued this dehumanizing trade but the harbor and the locale still evoke vivid images emblematic of the injustices done to the slaves.

Coincidently, $L B$ and POTC have shared a symbolic mask that penetrates their plots and settings at either ends; namely the mask of darkness which symbolizes the collective unconscious from where apparitions are revived so as to illuminate their fictional world as well as our consciousness. With the progress of the story in $L B$ and POTC, the mask of darkness gradually starts to be unveiled and other identities come to the stage. The first mask to be removed is that of Julian West as a member of the bourgeoisie who pursues luxuries but in fact he is against this ideology and his dream of future rights this strike done to the environmental balance. The dream foreshadows a collective discipline in which all members of the nation enjoy the same luxuries, privileges, rights, vacancies and receive equal share of the national income. Bellamy anticipates this radical change to the ideas and consolidation of the masses:

The inevitable consequence of even this comparative degree of intelligence had been a perception of the evils of society, such as had never before been general. It is quite true that these evils had been even worse, much worse, in previous ages. It was the increased intelligence of the masses which made the difference, as the dawn reveals the squalor of surroundings which in the darkness may have seemed tolerable. The key-note of the literature of the period was one of compassion for the 
poor and unfortunate, and indignant outcry against the failure of the social machinery to ameliorate the miseries of men. (Bellamy 2009, 164)

Similarly, removing the mask of darkness imposed by time on POTC the true identities of Mishlinya and Marnush are revealed. Their animation pinpoints their nostalgia for their old life as they had a betrothed and a wife with a child waiting for their return. They are not exhilarated to pursue their Christianity although it was the root cause of their concealment. Like Marnush, his wife and child had concealed their belief in Christianity for fear of execution and in turn, they attire in paganism and hid their relation to Marnush:

Yamlikha: It is the Christ who destined you to survive.

Marnush: Yes,...but what kind of survival is it that keeps me apart from my wife and son? Ah! Whenever I remember my son rising in the morning but I could not kiss him...

Yamlikha: How far do you love your family?

Marnush: I myself do live for them and their memory keeps me alive.

Yamlikha: Be patient! God's mercy is close-by.

Marnush: Really! Like the sky being close to the earth! Such mercy only saves those who could wait!

Yamlikha: Do not be ridiculous! ..God is right..

Marnush: God has nothing to do with us here. We are responsible for what has befallen us...nevertheless; I am in no charge of this inconvenience.

Yamlikha: We are all fated on this earth.

Marnush: Except for this situation....It was cause by a human being.

Yamlikha: (distasteful) forgiveness, a believer can hardly utter such words! (Al-hakim 2008, 12-13 t.m.)

Ironically, the unmasking of Marnush reveals his misconception of God and Christianity. Marnush is not a strong believer in Christianity like Yamlikha; the simplest and closest to nature of them all. Instead of instructing him, Yamlikha gives them a lesson and teaches them to be patient and faithful.

The mask of belief and piousness has fallen; Marnush and Mishlinya's faith becomes shakable and they doubt the true foundation of belief in Christianity and God. Yamlikha's simple and straightforward character reveals the weak and incomplete belief of Marnush and Mishlinya. Likewise, the closing words of Priska and Galias reveal her identity as murmured by Galias: "a woman that has 
fallen in love" (Al-hakim 2009, 117 t.m.) All along the drama, she attired a mask of a princess who just sympathizes with Mishlinya because of her likeness to his old betrothed. Her transformation has two reasons; the soothsayer's prophecy and Mishlinya's unshakable love. Unlike Priska, Edith has responded to the call of love earlier, she has been more sympathetic. Love arises as a kind of positive unmasking to the spirit of the age, the whole generation and the Leetes as well:

The crushing effect with which this belated perception of a fact so obvious came to me opened my eyes fully to something which perhaps the reader has already suspected,--I loved Edith.... My hosts evidently saw that I was depressed in spirits, and did their best to divert me. Edith especially, I could see, was distressed for me, but according to the usual perversity of lovers, having once been so mad as to dream of receiving something more from her, there was no longer any virtue for me in a kindness that I knew was only sympathy. (Bellamy 2009, 172-3)

Thus, the persona/mask archetype is utilized by Bellamy and Al-hakim variously to reveal true identities hidden behind other ready- molded ones colorfully attired. Metaphorically, the persona alludes to the overworking psyche which keeps on generating and reproducing dresses, masks and cloaks to conceal chronic processes running in either the personal or collective unconscious.

In conclusion, this paper has attempted to grapple with three basic dimensions necessary to analyze and understand both $L B$ and POTC; they are the real, the mythic, and the psychic. The paper has also introduced various definitions of mythology as a source from which writers have derived their stories, symbols, themes and characters. The dialectics whether the myth is a true story of the far past or a false one, a real history or just a kind of fantasy have been variously demonstrated. Next, the paper has handled Bulfinch's theories in which philosophers have classified myths into various categories such as the historical and the allegorical which have been applied on $L B$ and POTC. Dream theory and psychoanalysis have also been handled for their crucial role in the analysis of both works. It has become clear that dreams parallel myths as both have similar phases and they could be utilized to understand the human psyche. If dreams give voice to personal aspirations, myths as well reveal the aspirations of the whole nation. Jung's collective 
unconscious has also been highlighted with its inherited primordial thoughts which are equally shared by Bellamy and Al-hakim respectively in $L B$ and POTC. Finally, the research closes with Bellamy LB and Al-hakim's POTC as outstanding mythically grounded literary works and the manifested archetypes of the self, the shadow and the persona/mask. Finally, dreams and mythology have proved to be the ideal source where both the individual and the society could find answers to a great deal of their issues and foreshadow the future as well.

\section{Works Cited}

Abraham, Dr. Karl: Dreams and Myths: A Study in Race Psychology. Translated by William A. White, M.D. Washington, New York, The Journal of Nervous and Mental Disease Publishing Company, 1913. First reprinting 1970, Johnson Reprint Corporation.

Allen, Roger: An Introduction to Arabic Literature. Cambridge University Press, N.Y., USA 2003.

Badawi, M M: "A Passion for Experimentation: the Novels and Plays of Tawfiq Al-hakim". Third World Quarterly, published by Tailor and Francis vol. 10, No. 2 Islam and Politics (Apr., 1988) pp. 949-960.

Modern Arabic Drama in Egypt. Cambridge University Press, N.Y 1987.

Baldick, Chris: The Oxford Dictionary of Literary Terms. Oxford University Press, New York 2008.

Barthes, Roland: Mythologies. The Noonday Press, New York, USA, 1991.

Bellamy, Edward: Edward Bellamy Speaks Again! The Peerage Press, Kansas

City, Missouri,1937.

......., .....: Equality. Cosimo Classics Books, New York, 2007

......., ......: Looking Backward 2000-1887. Oxford University Press, New York, 2009.

Beaumont, Matthew: Utopia Ltd. Ideologies of Social Dreaming in England 1870-1900. Koninklijke Brill NV. Leiden • The Netherlands, 2005.

Bulfinch, Thomas: Bulfinch's Mythology, The Age of Fable or Beauties of Mythology. Dell Publishing, New York, U.S.A, 1967. 
Campbell, Joseph: Pathways to Bliss: Mythology and Personal Transformation.

New World Library, California, U.S.A, 2004.

: The Hero with A Thousand Faces. Princeton University Press,

Princeton, New Jersey, U.S.A., 2004

...: The power of Myth with Bill Moyers. (Betty Sue Flowers Ed.) Anchor

Books Doubleday, New York, London, Toronto, Sydney, Auckland, 1988

Cassirer, Ernest: The Myth of the State. New Haven, Yale University Press, London, U.K, 1961

Coleman, J. A.: The Dictionary of Mythology. Arcturus Publishing Limited, London, U.K, 2007

Crowley, Vivianne: Jungian Spirituality. FW Media Inc., Cincinnati, OH, U.S.A. 2012

Dant, Tim: Critical Social Theory: Culture, Society and Critique. SAGE Publications Ltd., London, California, New Delhi, 2003

Dowden, Ken : The Uses of Greek Mythology. Routledge, London and New York, 2005

Drabble, Margaret and Jenny Stringer eds.,: Oxford Concise Companion to English Literature. Oxford University Press, New York, 2003.

Ellwood, Robert : The Politics of Myth: A Study of C. G. Jung, Mircea Eliade, and Joseph Campbell. State University of New York Press, New York 1999.

Franz, Marie- Louise Von: Archetypal Dimensions of the Psyche. Hambhala, Boston \& London, 2014.

Frye, Northrop: Anatomy of Criticism: Four Essays with a new foreword by Harold Bloom. Princeton University Press, Princeton and Oxford, 2000.

Fudge, Bruce: "The Men of the Cave: Tafsir, Tragedy and Tawfiq Al-hakim".

Arabica, Vol. LIV, Issue 1 (67-93) Koninklijke Brill NY, Leiden, 2007.

Hendy, Andrew Von: The Modern Construction of Myth. Indiana University Press, Bloomington\& Indianapolis, U.S.A, 2001

Jones, Marie D.: The Power of Archetypes. The Career Press Inc. New Jersey, United States, 2017

Jung, Carl Gustav: C.G. Jung Psychological Types. A revision by R.F.C. Hull of the translation by H.G. Baynes With a new foreword by John Beebe. Routledge, London and New York, 2017. : Jung Contra Freud. The 1912 New York Lectures on the Theory of

Psychoanalysis . With an introduction by Sonu Shamdasani, Translated by R.F.C. Hull. PHILEMQN SERIES, Published with the support of the Philemon Foundation, This book is part of the Philemon Series of the 
Philemon Foundation, Bollingen Series, Princeton University Press, Princeton and Oxford, 2012.

$\therefore$ The Collected Works. Editors Sir Herbert Read, Michael Fordhan,

M.D., M.R.C.P. Gerhard Adler, PH.D. Published for Bollingen Foundation by Pantheon Books INC., New York, N. Y. 1961.

: Memories, Dreams, Reflections by C. G. Jung. Recorded and edited

by Aniela Jaffe, Translate from the German by Richard and Clara Winston,

Revised edition. Vintage Books, A Division of Random House, Inc. NEW YORK, 1989.

: The Archetypes and the Collective Unconscious. Second Edition,

Translated by R. F. C. HULL, ROUTLEDGE, London, 1980

M, Emelda.: "Difference Between Fable and Myth."

http://www.differencebetween.net/language/words-language/differencebetween-fable-and-myth/. July 12, 2011.

Morales, Helen: Classical Mythology: A Very Short Introduction. Oxford University Press, Oxford, U.K, 2007

Morgan, Arthur E.: The Philosophy of Edward Bellamy. King's Crown Press, New York, 2006.

Roudinesco, Élisabeth: Freud in his Time and Ours. Translated by Catherine Porter. Harvard University Press, U.S.A., 2016.

Shurter, Robert L.: "The Literary Work of Edward Bellamy", American Literature, vol. 5, no. 3 (Nov. 1933), pp. 229-234.

Strauss, Claude Levi: Myth and Meaning. Foreword by Wendy Doniger. Schocken Books, New York, U.S.A, 1995

WILLI, NORA LEE: Looking Back to Bellamy: American Political Theology for a New Gilded Age. University of Illinois at Chicago (Dissertation, 2018)

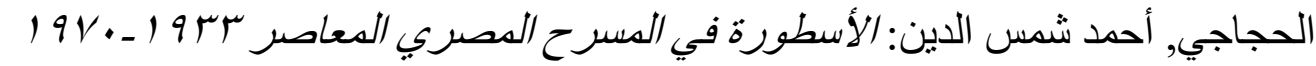

$$
\begin{aligned}
& \text { Myth in the Contemporary Egyptian Theatre 1933-1970 }
\end{aligned}
$$

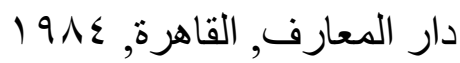

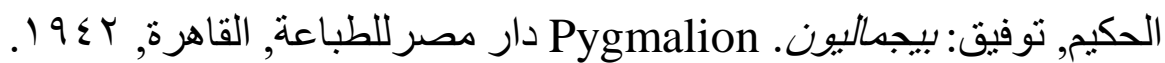

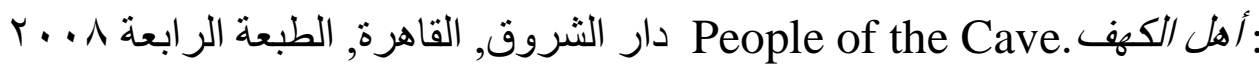

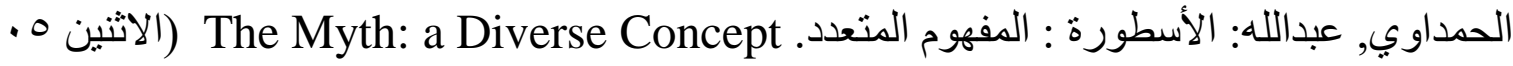

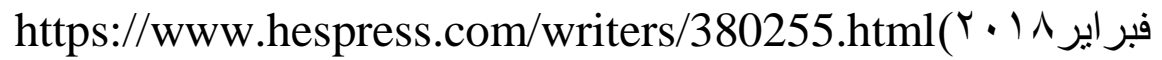

$$
\begin{aligned}
& \text { العشماوي, محمد زكي:بر اسات في النقد المسرحي والأدب الدقارن. } \\
& \text { Studies in Theatrical Criticism and Comparative Literature }
\end{aligned}
$$

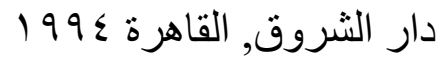




$$
\text { بلحاج, ربيحة: سيكولجية البطل في مسرحية أهل الكهف لتوفيق الحكيم. }
$$

The Psychology of the Hero in People of the Cave by Tawfiq Al-hakim

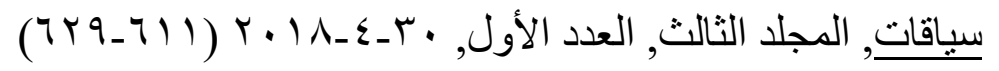

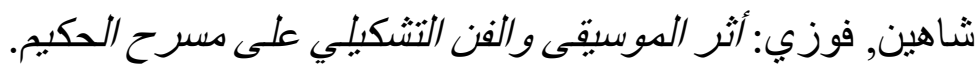
The Influence of Music and Fine Art on Al-hakim's Theatre الهيئة المصرية العامة للكتاب. القاهرة . 199

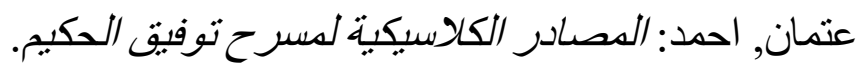
The classical Sources of Al-hakim's Theatre دار نوبار للطباعة. القاهرة بـو 199

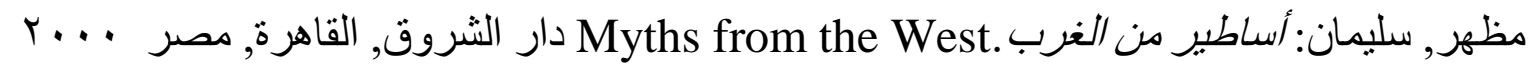

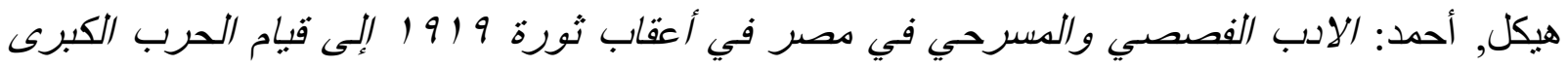

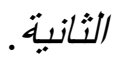

Narrative and Theatrical Arts in Egypt in the Wake of 1919 Revolution till the beginning of World War II

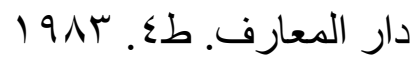

\section{List of Abbreviations:}

LB: Looking Backward 2000-1887

POTC: People of the Cave

TCW: The Collected Works of C.G. Jung

t.m.: The translation is mine. 


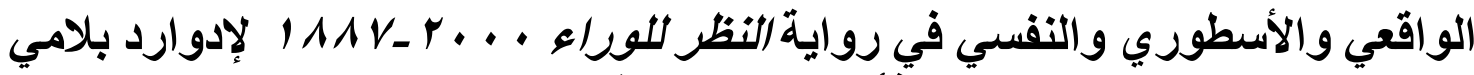

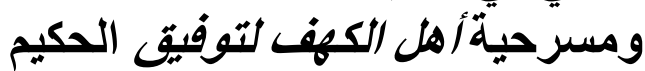

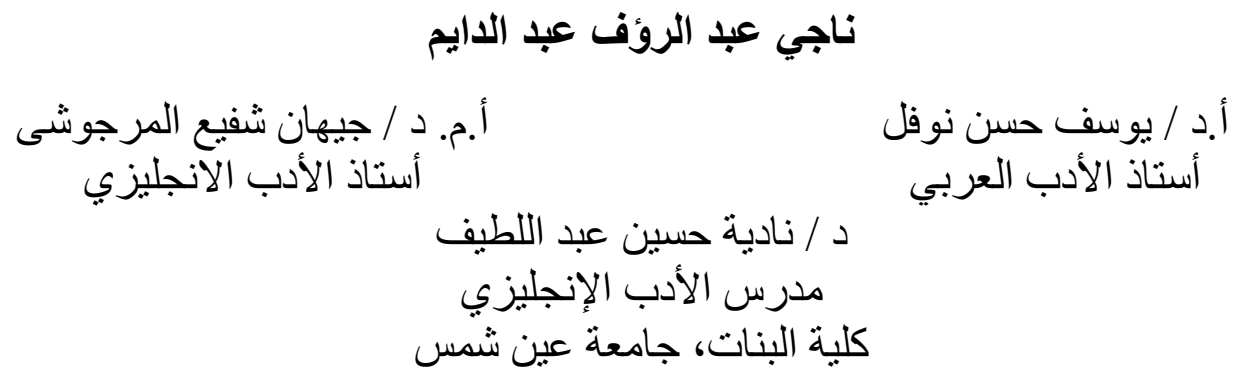

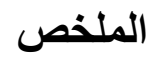

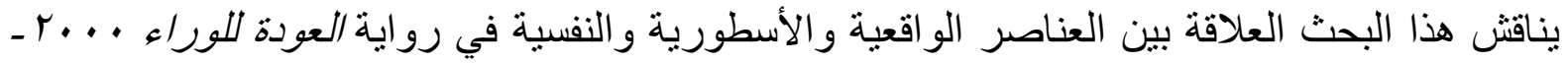

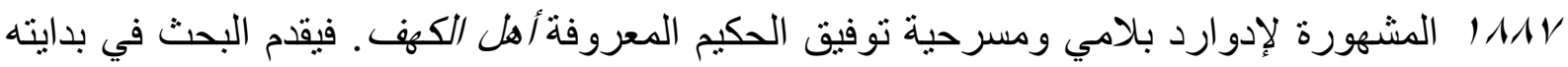

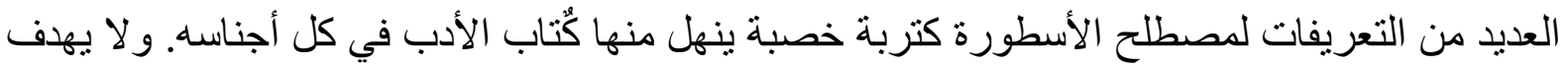

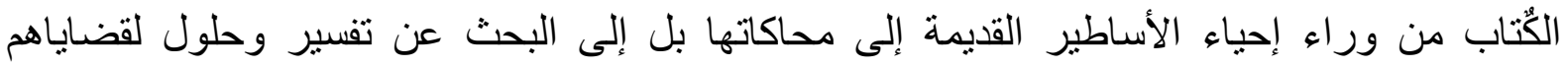

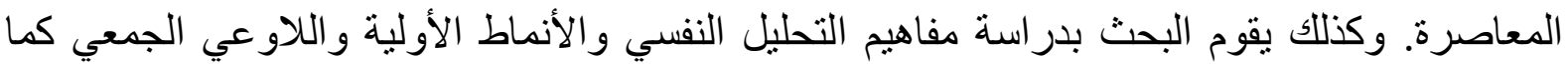

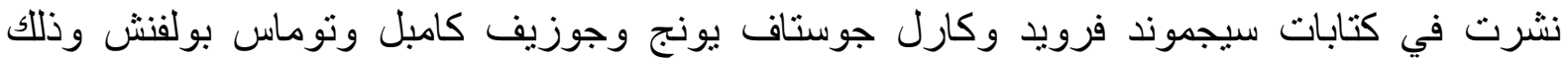

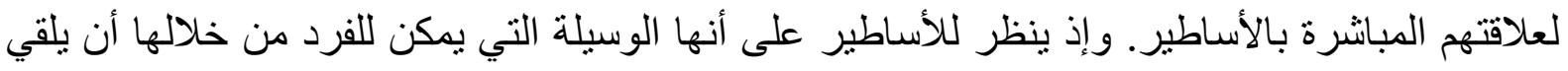

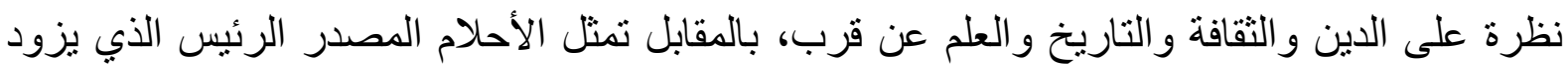

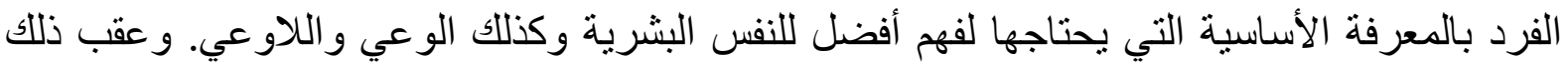

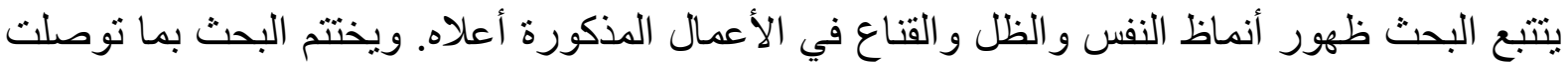
إليه هذه الدر اسة الئة 